Imlay, T. L., H. A. R. Mann, and M. L. Leonard. 2017. No effect of insect abundance on nestling survival or mass for three aerial insectivores. Avian Conservation and Ecology 12(2):19. https://doi.org/10.5751/ACE-01092-120219

Copyright $(C) 2017$ by the author(s). Published here under license by the Resilience Alliance.

Research Paper

\title{
No effect of insect abundance on nestling survival or mass for three aerial insectivores
}

\author{
Tara L. Imlay ${ }^{1}$, Hilary A. R. Mann ${ }^{1,2}$ and Marty L. Leonard ${ }^{1}$ \\ ${ }^{1}$ Biology Department, Dalhousie University, Halifax, NS, Canada, ${ }^{2}$ Wildlife Preservation Canada, Guelph, ON, Canada
}

\begin{abstract}
Swallows, along with other aerial insectivores, are experiencing steep population declines. Decreased insect abundance has been implicated as a potential cause of the decline. However, to determine if there is a guild-level effect of reduced insect abundance on swallows, research is needed to examine relationships between insect abundance and breeding success for multiple species. The goal of our study was two-fold. First, we determined if insect abundance during nestling rearing varied with breeding phenology for three species of swallows, Barn (Hirundo rustica), Cliff (Petrochelidon pyrrhonota), and Tree Swallows (Tachycineta bicolor), such that swallows breeding when insects are abundant have greater success. Then we determined if insect abundance was related to nestling survival and mass (as a proxy for postfledgling survival). We collected insects daily at each of three study sites during the breeding season, monitored swallow nests to determine breeding phenology and success, and weighed nestlings at or just prior to the peak of rapid nestling growth to determine mass. We found early hatching Cliff and Tree Swallow nests had higher insect abundance during nestling rearing. However, neither nestling survival nor mass were related to insect abundance. Our results suggest that breeding success in three species of swallows was not related to insect abundance in our study area. We suggest that the role of insect abundance on aerial insectivore declines may vary across their geographic range, and call for broad-scale, multispecies research on aerial insectivore declines.
\end{abstract}

\section{Absence d'effet du nombre d'insectes sur la survie et le poids des oisillons de trois insectivores aériens}

RÉSUMÉ. Les populations d'hirondelles, tout comme celles d'autres insectivores aériens, affichent des baisses marquées. Pour expliquer celles-ci, la diminution du nombre d'insectes a été soulevée comme cause possible. Toutefois, des études examinant la relation entre la quantité d'insectes et le succès de reproduction de plusieurs espèces sont nécessaires afin de déterminer si la quantité réduite d'insectes a un effet sur l'ensemble des espèces d'hirondelles. La présente étude avait deux objectifs. Le premier était de déterminer si la quantité d'insectes durant l'élevage des oisillons variait en fonction de la phénologie de nidification de trois espèces d'hirondelles, l'Hirondelle rustique (Hirundo rustica), l'Hirondelle à front blanc (Petrochelidon pyrrhonota) et l'Hirondelle bicolore (Tachycineta bicolor), de sorte que les hirondelles qui nichent au moment où les insectes sont nombreux devraient avoir un meilleur succès que celles qui ne le font pas. Le second objectif était de déterminer si la quantité d'insectes était reliée à la survie et au poids des oisillons (comme indicateur de la survie des jeunes ayant pris leur envol). Nous avons récolté quotidiennement des insectes à chacun des trois sites d'étude durant la saison de nidification, suivi des nids d'hirondelles afin de déterminer la phénologie et le succès de nidification, et pesé les oisillons au moment du pic de prise rapide de poids ou tout juste avant. Nous avons observé que les Hirondelles à front blanc et bicolores dont les nids ont éclos plus tôt disposaient d'une plus grande quantité d'insectes au moment de l'élevage des oisillons. Néanmoins, ni la survie ni le poids des oisillons n'étaient relié à la quantité d'insectes. Nos résultats indiquent que le succès de reproduction de trois espèces d'hirondelles n'était pas relié à la quantité d'insectes dans notre aide d'étude. Nous pensons que le rôle de la quantité d'insectes sur la diminution des insectivores aériens peut varier dans l'ensemble de leur aire et recommandons que des recherches ciblant la diminution des insectivores aériens soient entreprises à grande échelle et sur plusieurs espèces à la fois.

Key Words: body condition; food availability; reproductive success

\section{INTRODUCTION}

Parental care affects the fitness of both adults and their young, and, for birds, parental care includes behaviors related to nestsite selection, nest building, incubation, brooding, predator deterrence, and food provisioning (Owens and Bennett 1994, Soler et al. 1998, Lima 2009). These aspects of parental care are costly, so many species offset the demands of breeding by timing their breeding to occur during favorable conditions, like during periods of high food availability (Martin 1987). For some species, this can involve timing periods of high food demand from nestlings with short-lived peaks in food abundance, e.g., caterpillar emergence (Both et al. 2006, 2009, Visser et al. 2006). For other species, however, such as some swallows, seasonal trends in food abundance may vary and have no discernable peaks (Hussell and Quinney 1987, Grüebler and Naef-Daenzer 2008, Dunn et al. 2011), making it difficult for birds to anticipate periods of high or low food abundance. Regardless of the trend in food availability, breeding that occurs when there are adequate food supplies for adults as well as their young will maximize reproductive success and survival. 
For nestlings, food availability can impact growth, development, and survival. Low food availability is associated with reduced nestling mass (Brzęk and Konarzewski 2004, Burger et al. 2012), delayed feather growth resulting in shorter feathers at fledging (McCarty and Winkler 1999a, Hovorka and Robertson 2000), and reduced survival to fledging (Boulton et al. 2008). Low food availability can have a greater impact on nestlings during periods of rapid growth and development (Winkler et al. 2013). Low food availability during the nestling period can also negatively impact postfledgling survival and recruitment because young fledge in worse condition than after periods of high food availability (Møller 1994, McCarty 2001, Schwagmeyer and Mock 2008). In addition to food availability, quality can also affect nestling growth and development (de Ayala et al. 2006, Twining et al. 2016).

Swallows, along with other aerial insectivores, i.e., birds that feed in the air during flight, are experiencing severe and widespread population declines across most of North America, particularly in the northeast (Nebel et al. 2010, Smith et al. 2015, Michel et al. 2016). The temporal and spatial synchrony in population declines suggest that there is a common threat(s) affecting aerial insectivores (Nebel et al. 2010, Smith et al. 2015, but see Michel et al. 2016). The most obvious common factor is that these species all rely on aerial insects for food. Therefore it has been hypothesized that reductions in insect abundance may be driving these trends (Nebel et al. 2010, Shutler et al. 2012). These reductions could be the result of a mistiming between peak insect abundance and offspring demands. For instance, swallows in the Maritime provinces of Canada have advanced their breeding by 8-10 days over the last 57 years (T. L. Imlay, J. Mills Flemming, S. Saldanha, et al., unpublished manuscript) providing the potential for mistiming to occur (but see Dunn et al. 2011). Alternatively, reductions in insect abundance could be a result of changes to the ecosystem that have reduced overall abundance (Nebel et al. 2010). For example, agricultural intensification, i.e., conversion of hayfields and pastures to row crops, is associated with lower abundance of dipterans, a common swallow food item (Rioux Paquette et al. 2013).

Relationships between insect abundance and swallow breeding success, especially nestling and postfledgling survival, have been investigated for Tree Swallows (e.g., Quinney et al. 1986, McCarty and Winkler 1999a, Nooker et al. 2005) and to a lesser extent for other species (e.g., Grüebler and Naef-Daenzer 2008). However, research examining these relationships with multiple species simultaneously has not been conducted. Understanding if insect abundance has a consistent effect on breeding success across several species may help to determine if there is a common factor influencing declines. To that end, we examined the relationships between insect abundance and the breeding success of Barn (Hirundo rustica), Cliff (Petrochelidon pyrrhonota), and Tree Swallows (Tachycineta bicolor), in an area with steep population declines (Sauer et al. 2014). Specifically, we determined if the timing of breeding, i.e., hatching dates, was related to periods of low insect abundance during nestling rearing, and then determined if insect abundance during nestling rearing was related to nestling survival and mass, which serves as a proxy for postfledging survival (reviewed in Naef-Daenzer and Grüebler 2016).

\section{METHODS}

In 2014 and 2015, we monitored Barn, Cliff, and Tree Swallows at three sites within $30 \mathrm{~km}$ of Sackville, New Brunswick (45 $54^{\prime} 6$ " N 6421'47" W). The first site (BEFV) was a mix of active hayfields (mowed at least once annually), old hayfields (not mowed during our study), wet meadows, and open, cattail wetlands. At this site, Barn Swallows nested in a barn, under a deck, and in a carport near the active and old hayfields. Tree Swallows nested in the 45 boxes located at the periphery of the active hayfields and adjacent to cattail wetlands. The second site (JO) was a mix of actively grazed cattle pasture, and mostly grassy areas with a few shrubs adjacent to a lake and bordered by a narrow stand of coniferous trees. At this site, Barn Swallows nested in a barn and Cliff Swallows nested under the eaves of farm buildings surrounded by the pasture. Tree Swallows nested in 41 boxes in the area adjacent to the lake and near the pasture. The third site (WE) was a mix of actively grazed pasture for cattle and sheep, active hayfields, and a wet meadow that was frequently flooded from a nearby open cattail wetland. Barn and Cliff Swallows nested in and under the eaves, respectively, of the farm buildings surrounded by pasture. Tree Swallows nested in 20 boxes located along the edges of the pasture, hayfield, and wet meadow.

To determine hatching date and brood size, we typically checked swallow nests every 2-3 days during the breeding season, with more frequent checks, i.e., every two days, around the earliest projected hatching date. Because nests were not checked daily, hatching date was determined by the size and feather development of nestlings once hatched. In the event of asynchronous hatching, hatching date was defined as the day most young hatched (usually the first day of hatching). Nests were infrequently checked until nestling banding and the final check on day 12 posthatch. Nestling survival after day 10 is high $(\geq 95 \%)$ for these species (Brown and Bomberger Brown 1999a, Ambrosini et al. 2002), therefore the number of nestlings at day 12 should reflect fledging success. We banded nestlings with Canadian Wildlife Service aluminum bands and measured the mass of all nestlings at or near the point when growth rate was highest for each species (Barn: day 9 posthatch; Cliff: day 10; Tree: day 12; Stoner 1935, 1945, Brown and Bomberger Brown 1996, McCarty 2001). Nestling mass is positively correlated with postfledgling, i.e., juvenile, survival for Barn and Cliff Swallows (Brown and Bomberger Brown 1996, Naef-Daenzer and Grüebler 2016), therefore we used mass as a proxy for postfledgling survival. However, we recognize that postfledgling mass and fledge date (not measured during this study) may also affect postfledgling survival (Raja-aho et al. 2017).

Using similar methods to previous studies (Quinney et al. 1986, Hussell and Quinney 1987, Hussell 1988, 2012, Dunn et al. 2011), we measured insect abundance at our study sites by collecting two insect samples/day/site using two stationary conical nets. The insect sampling period included 10 June-24 July 2014 and 8 June16 July 2015, and included samples from the first day swallow nestlings hatched to 12 days after the last of the first nests hatched. We did not collect insect samples during the nestling period of second nests either following a failed [all species] or successful [Barn] first nest. At each site, two nets were placed in open fields near wetlands 5-20 m from the closest Tree Swallow nest box and 25-140 $\mathrm{m}$ from the closest farm buildings that provided nesting sites for Barn and Cliff Swallows. The nets were positioned $1.6 \mathrm{~m}$ 
above the ground and could rotate freely. A sample jar containing $100 \%$ ethanol was placed in the net between 06:00 and 10:00 and collected between 15:00 and 20:30, for, on average a sampling period of $8.57 \pm 0.05$ [SE] hours/day/jar. Each sample was airdried for 24 hours and the dried mass was measured. We calculated an index of daily insect abundance at each site by dividing dried insect mass for each sample by the amount of time the jar was in place, averaging the results for both nets at the site and log transforming the mean to normalize the data. Using this method, previous work has found relationships between mean daily insect abundance and Tree Swallow clutch initiation dates (Hussell and Quinney 1987, Dunn et al. 2011), clutch sizes (Hussell and Quinney 1987), nestling diets (Quinney and Ankney 1985), nestling begging (Hussell 1988), growth and survival (Quinney et al. 1986), and nest-box occupancy (Hussell 2012).

In 2014, we identified the insects to order. The most common insects at our site were (in order of greatest total mass) Diptera, Coleoptera, and Hymenoptera; together these insects accounted for $86.5 \%$ of the mass in our samples. All three species of swallows forage on insects in these orders, but there is interspecific and geographic variation in the amount of insects consumed in each order (summarized in Brown and Bomberger Brown 1999b, Winkler et al. 2011, Brown et al. 2017). Some research has found selection for Hymenoptera by Barn Swallows (Law et al. 2017) and larger insects $(>3 \mathrm{~mm}$ ) by Tree Swallows (McCarty and Winkler 1999b), but it is unclear if prey selection is consistent across populations.

\section{Data analysis}

First, to determine if insect abundance during the nestling period varied with the timing of breeding, i.e., hatching date (HD), we used a general linear model for each species. We considered the nestling period for each nest to be from the hatch date until the last nest check on day 12; insect abundance was averaged across these 12 days $\left(\mathrm{IA}_{\mathrm{M}}\right)$. We compared eight different models including all possible combinations of HD, site, and year, and a null model. If we found a seasonal decline in $\mathrm{IA}_{\mathrm{M}}$, then this could explain seasonal declines in breeding success (Møller 1994, Brown and Bomberger Brown 1999a, Wardrop and Ydenberg 2003, Dawson 2008).

Then, to determine if nestling survival was related to insect abundance, we used a generalized linear model with a binomial distribution that included the number of surviving and dead young at day 12 for each nest, and a complementary log-log link function for each species. For all three species, we identified two groups of models. These groups of models started with two base models containing either mean insect abundance during the nestling period $\left(\mathrm{IA}_{\mathrm{M}}\right)$ or HD. Hatching date provides a proxy for other seasonal factors, like weather, parasitism, and pressure to migrate (reviewed in Verhulst and Nilsson 2008) that could affect nestling survival. We did not include $\mathrm{IA}_{\mathrm{M}}$ and $\mathrm{HD}$ in the same models because they were related for Cliff and Tree Swallows (see Tables 1 and 2). For Cliff and Tree Swallows, we added all possible combinations of brood size, site, and year as possible covariates to our two base models, i.e., $\mathrm{IA}_{\mathrm{M}}$ and HD, for a total of 14 models. The small number of Barn Swallow nests ( $n=2$ of 29; Fig. 1) that experienced the loss of at least one nestling during our study, affected our ability to add additional covariates to our base models. Our 3rd (Barn) or 17th (Cliff and Tree) model was a null model that did not include any covariates. We excluded four Tree Swallow nests from this analysis because nestling mortality was due to factors unrelated to insect abundance, i.e., predation (2), nest box knocked over by high winds (1), and a tractor (1).

Table 1. Best-fit models for insect abundance during nestling rearing for Barn (Hirundo rustica), Cliff (Petrochelidon pyrrhonota), and Tree Swallows (Tachycinetabicolor). Of the eight possible models for each species, only models with a wi $\geq 0.05$ are included.

\begin{tabular}{llcccc}
\hline \hline Species & Model $^{\dagger}$ & $\mathrm{K}^{\ddagger}$ & $\Delta \mathrm{AICc}^{\S}$ & $\mathrm{w}_{\mathrm{i}}$ & Deviance \\
\hline Barn & null & 1 & 0.0 & 0.74 & 0.58 \\
& year & 3 & 3.9 & 0.11 & 0.55 \\
Cliff & HD + year & 4 & 0.0 & 0.70 & 0.50 \\
& HD + site + year & 7 & 2.5 & 0.21 & 0.50 \\
& HD & 2 & 4.7 & 0.07 & 0.58 \\
Tree & HD & 2 & 0.0 & 0.64 & 1.56 \\
& HD + year & 4 & 2.4 & 0.20 & 1.56 \\
& HD + site & 5 & 3.3 & 0.13 & 1.54 \\
\hline
\end{tabular}

${ }^{\dagger}$ Abbreviation: HD = hatching date.

Number of parameters

${ }^{\S} \mathrm{AIC} c$ values for top model: Barn -28.8; Cliff -82.2; Tree -198.7.

Table 2. Model coefficients with SE and confidence intervals (CI) from the best-fit models for the relationship between insect abundance during nestling rearing and hatching date for Cliff (Petrochelidon pyrrhonota) and Tree Swallows (Tachycineta bicolor). The best-fit models for Barn Swallows (Hirundo rustica) was the null model and is not included in the table.

\begin{tabular}{llcccc}
\hline \hline Species & Coefficients ${ }^{\dagger}$ & Estimate & SE & $\begin{array}{c}\text { Lower 95\% } \\
\text { CI }\end{array}$ & $\begin{array}{c}\text { Upper 95\% } \\
\text { CI }\end{array}$ \\
\hline Cliff & intercept & 0.21 & 0.15 & -0.09 & 0.51 \\
& HD & -0.01 & 0.00 & -0.02 & -0.01 \\
& year 2015 & -0.08 & 0.03 & -0.14 & -0.02 \\
Tree & intercept & -0.36 & 0.01 & -0.38 & -0.34 \\
& HD & -0.20 & 0.02 & -0.24 & -0.16 \\
\hline
\end{tabular}

${ }^{\dagger}$ Abbreviation: $\mathrm{HD}=$ hatching date.

Fig. 1. Proportion of Barn (Hirundo rustica), Cliff (Petrochelidon pyrrhonota), and Tree Swallow (Tachycineta bicolor) nests that experienced no (white), some (grey), or complete (black) nestling mortality. Number of nests: Barn 29; Cliff 50; Tree 129.

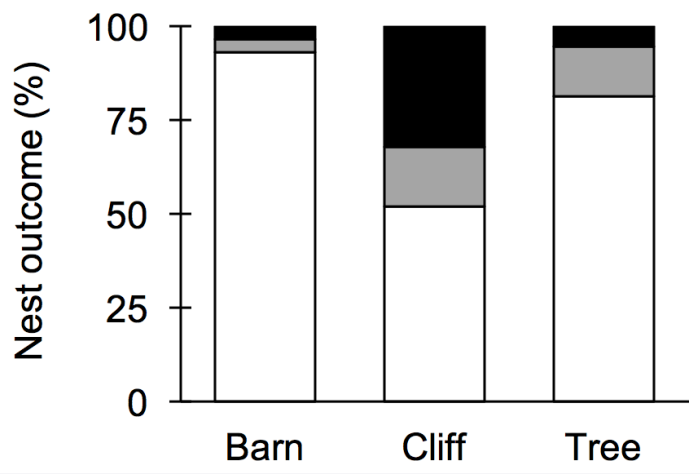


Finally, to determine the relationship between the mean mass of all nestlings in a brood (as an indicator of postfledgling survival) and mean insect abundance, we used a general linear mixed model for each species. Because extremely low mean nestling masses (often due to several "runt" offspring that die in the nest) are not predictive of postfledgling survival (Wardrop and Ydenberg 2003), we excluded one Barn, three Cliff, and two Tree Swallow nests with a mean nestling mass more than two standard deviations below the mean for all nests. Previous work on Tree Swallows indicates that although nestling mass is influenced by insect abundance throughout the nestling period, it is most strongly affected by insect abundance during the period of rapid growth that occurs shortly before young are banded (McCarty and Winkler 1999a). Therefore, we selected two measures of insect abundance: (1) mean insect abundance during nestling rearing up to and including banding day ( $\mathrm{IA}_{\mathrm{MB}}$ : Barn: day 1-9; Cliff: day 110; and Tree: day 1-12); and (2) mean insect abundance on and one day prior to banding day ( $\mathrm{IA}_{\mathrm{B} 1}$ : Barn: day 8-9; Cliff: day 910; and Tree: day 11-12).

Similar to our analysis on nestling survival, we identified three groups of models. For all three species, we started with three base models containing $\mathrm{IA}_{\mathrm{MB}}, \mathrm{IA}_{\mathrm{B} 1}$ or hatching date (HD). Then, for Cliff and Tree Swallows, we added all possible combinations of brood size, site, and year as possible covariates to our three base models (i.e., $\mathrm{IA}_{\mathrm{MB}}, \mathrm{IA}_{\mathrm{B} 1}$ and $\mathrm{HD}$ ) for a total of 21 models. Our 4th (Barn) and 25th (Cliff and Tree) model was a null model that did not include any fixed effects. All of these models included a random variable for nest ID.

We determined the best-fit model for hatching date, nestling survival, and mean mass by comparing the Aikake's Information Criterion with the small sample size correction (AICc) and the weight $\left(\mathrm{w}_{\mathrm{i}}\right)$ given to each model (Burnham and Anderson 2002). If two or more models had a $\triangle \mathrm{AICc}<2.0$, then we averaged the models to determine our parameter estimates and the relative importance of each variable. We were interested in the variables that had the greatest effect on our response, therefore we used the zero method for model averaging (Nakagawa and Freckleton 2011). Any variables included in our best-fit or averaged models with unconditional confidence intervals that included zero, were deemed to have little support. We centered and scaled all continuous variables (i.e., $\mathrm{IA}_{\mathrm{M}}, \mathrm{IA}_{\mathrm{MB}}, \mathrm{IA}_{\mathrm{B} 1}$ and $\mathrm{HD}$ ) in our models (Grueber et al. 2011). All analyses were performed in R Studio version 0.99.903 (RStudio Team 2015, R Core Team 2016) using the packages bblme version 1.0.18, lme4 (Bates et al. 2015), MuMln version 1.15.6 (Barton 2016), and plyr version 1.8.4 (Wickham 2011). Mean values are presented with the standard error $( \pm S E)$, and the variation in our variables is presented in Table A1.1.

\section{RESULTS}

\section{Hatching date}

For Barn Swallows, our best-fit model examining the relationship between hatching date and mean insect abundance during nestling rearing was the null model (Table 1), indicating that insect abundance during nestling rearing was not related to hatching date, site, or year. For Cliff and Tree Swallows, our best-fit models included hatch date (Table 1). Cliff and Tree Swallow nests that hatched earlier had higher insect abundance during nestling rearing than nests that hatched later (Table 2). For Cliff Swallows, insect abundance during nestling rearing was also higher in 2014 compared to 2015 .

\section{Nestling survival}

During our study, nestling survival was high for Barn and Tree Swallows $(96.8 \%$ and $90.7 \%$ surviving from hatch to day 12 , respectively), but lower for Cliff Swallows (65.5\%; Fig. 1, Table A1.1). For Barn Swallows, our top two models $(\triangle \mathrm{AICc} \leq 2.0)$ for predicting nestling survival included $\mathrm{IA}_{\mathrm{M}}$ and the null model (Table 3). However, model averaged confidence intervals for $\mathrm{IA}_{\mathrm{M}}$ included zero, indicating little evidence that this variable affected nestling survival (Table 4).

Table 3. Best-fit models for Barn (Hirundo rustica), Cliff (Petrochelidon pyrrhonota), and Tree Swallow (Tachycineta bicolor) nestling survival. Of the three (Barn) or 17 (Cliff and Tree) possible models, only models with a wi $\geq 0.05$ are listed. Models with a $\triangle \mathrm{AICc} \leq 2.0$ were averaged to determine parameter estimates.

\begin{tabular}{|c|c|c|c|c|c|}
\hline Species & Model $^{\dagger}$ & $\mathrm{K}^{\ddagger}$ & $\triangle \mathrm{AICc}^{\S}$ & $\mathrm{w}_{\mathrm{i}}$ & Deviance \\
\hline \multirow[t]{3}{*}{ Barn } & $\mathrm{IA}_{\mathrm{M}}$ & 1 & 0.0 & 0.53 & 30.84 \\
\hline & null & 1 & 0.9 & 0.34 & 27.65 \\
\hline & HD & 1 & 2.7 & 0.14 & 30.35 \\
\hline \multirow[t]{4}{*}{ Cliff } & $\mathrm{HD}+$ year & 3 & 0.0 & 0.36 & 129.54 \\
\hline & HD + brood size + year & 4 & 0.7 & 0.25 & 127.90 \\
\hline & $\mathrm{HD}+$ site + year & 5 & 1.0 & 0.22 & 128.12 \\
\hline & $\mathrm{HD}+$ brood & 6 & 1.6 & 0.16 & 126.23 \\
\hline \multirow[t]{8}{*}{ Tree } & $\mathrm{IA}_{\mathrm{M}}+$ site + year & 6 & 0.0 & 0.26 & 242.56 \\
\hline & $\mathrm{HD}+$ site + year & 6 & 0.8 & 0.18 & 243.31 \\
\hline & $\mathrm{IA}_{\mathrm{M}}+$ year & 3 & 1.0 & 0.16 & 247.85 \\
\hline & $\mathrm{HD}+$ year & 3 & 1.3 & 0.14 & 248.11 \\
\hline & $\mathrm{IA}_{\mathrm{M}}+$ brood size + & 7 & 2.0 & 0.09 & 242.38 \\
\hline & $\mathrm{HD}+$ brood size + site + year & 7 & 2.6 & 0.07 & 242.93 \\
\hline & $\mathrm{IA}_{\mathrm{M}}+$ brood size + & 4 & 3.1 & 0.06 & 247.78 \\
\hline & HD + brood size + year & 4 & 3.2 & 0.05 & 247.96 \\
\hline
\end{tabular}

${ }^{\dagger}$ Abbreviations: $\mathrm{IA}_{\mathrm{M}}=$ mean insect abundance up to and including day 12 ; and $\mathrm{HD}=$ hatching date

${ }^{\dagger}$ Number of parameters

${ }^{\S}$ AICc values for top model: Barn 33.8; Cliff 149.5; Tree 283.4

For Cliff Swallows, our top four best fitting models $(\triangle \mathrm{AICc} \leq 2.0)$ for nestling survival included hatch date, year, and various combinations of brood size and site (Table 3). Model averaged parameter estimates showed that hatching date and year were the most important predictors of nestling survival (Table 4). Nestling survival was higher in earlier hatching nests, and in 2015 compared to 2014. Model averaged confidence intervals for brood size and site included zero, indicating little evidence that these variables affected nestling survival.

For Tree Swallows, our top five best fitting models $(\triangle \mathrm{AICc} \leq 2.0)$ for nestling survival included $\mathrm{IA}_{\mathrm{M}}$ or $\mathrm{HD}$, and various combinations of brood size, site, and year (Table 3). Model averaged parameter estimates showed that site and year were the most important predictors of nestling survival (Table 4). Nestling survival was higher at BEFV than JO but similar to WE (Table A1.1), and in 2014 compared to 2015. Again, model averaged confidence intervals for $\mathrm{IA}_{\mathrm{M}}, \mathrm{HD}$, and brood size included zero, indicating little evidence that these variables affected nestling survival. 
Table 4. Averaged model coefficients with adjusted SE and confidence intervals (CI) from the best-fit models for Barn (Hirundo rustica), Cliff (Petrochelidon pyrrhonota), and Tree Swallow (Tachycineta bicolor) nestling survival.

\begin{tabular}{|c|c|c|c|c|c|c|}
\hline Species & Coefficients $^{\dagger}$ & Estimate & $\overline{\mathrm{SE}}$ & Lower 95\% CI & Upper $95 \% \mathrm{CI}$ & Relative importance $\left(\mathrm{S}^{\dagger}\right)$ \\
\hline \multirow[t]{2}{*}{ Barn } & intercept & 1.29 & 0.17 & 0.95 & 1.64 & - \\
\hline & $\mathrm{IA}_{\mathrm{M}}$ & -0.35 & 0.37 & -1.20 & 0.05 & $0.61(1)$ \\
\hline \multirow[t]{5}{*}{ Cliff } & intercept & -0.41 & 0.21 & -0.84 & 0.01 & - \\
\hline & HD & -1.82 & 0.43 & -2.69 & -0.95 & $1.00(4)$ \\
\hline & brood size & 0.15 & 0.26 & -0.20 & 0.95 & $0.42(2)$ \\
\hline & site WE & -0.14 & 0.24 & -0.88 & 0.17 & $0.39(2)$ \\
\hline & year 2015 & 1.02 & 0.30 & 0.41 & 1.63 & $1.00(4)$ \\
\hline \multirow[t]{7}{*}{ Tree } & intercept & 1.41 & 0.16 & 1.09 & 1.73 & - \\
\hline & $\mathrm{IA}_{\mathrm{M}}$ & -0.08 & 0.11 & -0.36 & 0.10 & $0.63(3)$ \\
\hline & HD & 0.03 & 0.09 & -0.14 & 0.32 & $0.38(2)$ \\
\hline & brood size & 0.00 & 0.02 & -0.09 & 0.14 & $0.11(1)$ \\
\hline & site JO & -0.20 & 0.19 & -0.60 & -0.02 & 0.64 (3) \\
\hline & site WE & -0.12 & 0.15 & -0.47 & 0.09 & 0.64 (3) \\
\hline & year 2015 & -0.62 & 0.13 & -0.87 & -0.37 & $1.00(5)$ \\
\hline
\end{tabular}

${ }^{\dagger}$ Abbreviations: $\mathrm{IA}_{\mathrm{M}}=$ mean insect abundance up to and including day 12 ; and $\mathrm{HD}=$ hatching date.

Number of averaged models.

\section{Nestling mass}

For Barn Swallows, our top two best-fit models $(\triangle \mathrm{AICc} \leq 2.0)$ for nestling mass included insect abundance on and one day prior to banding $\left(\mathrm{IA}_{\mathrm{B} 1}\right)$ and mean insect abundance from hatch to banding day $\left(\mathrm{IA}_{\mathrm{MB}}\right)$ (Table 5). Model averaged confidence intervals for $\mathrm{IA}_{\mathrm{B} 1}$ and $\mathrm{IA}_{\mathrm{MB}}$ included zero, indicating little evidence that insect abundance affected nestling mass (Table 6).

Table 5. Best-fit models for Barn (Hirundo rustica), Cliff (Petrochelidon pyrrhonota), and Tree Swallow (Tachycineta bicolor) nestling mass. Of the four (Barn) and 25 (Cliff and Tree) possible models for each species, only models with a wi $\geq 0.05$ are included. Models with a $\triangle \mathrm{AICc} \leq 2.0$ were averaged to determine parameter estimates.

\begin{tabular}{llcccc}
\hline \hline Species & Model $^{\dagger}$ & $\mathrm{K}^{\ddagger}$ & $\Delta \mathrm{AICc}^{\S}$ & $\mathrm{w}_{\mathrm{i}}$ & Deviance \\
\hline Barn & $\mathrm{IA}_{\mathrm{B} 1}$ & 1 & 0.0 & 0.59 & 1419.86 \\
& $\mathrm{IA}_{\mathrm{MB}}$ & 1 & 1.8 & 0.24 & 1421.67 \\
& $\mathrm{HD}$ & 1 & 2.6 & 0.16 & 1422.43 \\
Cliff & $\mathrm{HD}+$ brood size + site + year & 6 & 0.0 & 0.27 & 649.19 \\
& $\mathrm{HD}+$ site + year & 5 & 0.1 & 0.26 & 651.48 \\
& $\mathrm{IA}_{\mathrm{B} 1}+$ site + year & 5 & 0.8 & 0.18 & 652.25 \\
& $\mathrm{IA}_{\mathrm{MB}}+$ site + year & 5 & 1.6 & 0.12 & 653.05 \\
& $\mathrm{IA}_{\mathrm{B} 1}+$ brood size + site + year & 6 & 2.4 & 0.08 & 651.59 \\
& $\mathrm{IA}_{\mathrm{MB}}+$ brood size+ site + year & 6 & 2.9 & 0.06 & 652.08 \\
Tree & 1 & 0.0 & 0.27 & 2331.79 \\
& null & 1 & 0.7 & 0.19 & 2330.42 \\
& $\mathrm{HD}$ & 1 & 2.2 & 0.09 & 2332.01 \\
& $\mathrm{IA}_{\mathrm{MB}}$ & 4 & 2.3 & 0.09 & 2327.94 \\
& $\mathrm{HD}+$ site & 1 & 2.3 & 0.08 & 2332.09 \\
& $\mathrm{IA}_{\mathrm{B} 1}$ & 3 & 2.8 & 0.07 & 2330.50 \\
& $\mathrm{HD}+$ year &
\end{tabular}

${ }^{\dagger}$ Abbreviations: $\mathrm{IA}_{\mathrm{B} 1}=$ mean insect abundance on and one day prior to banding day; $\mathrm{IA}_{\mathrm{MB}} \stackrel{\mathrm{B1}}{=}$ mean insect abundance up to and including banding day; and $\mathrm{HD}=$ hatching date

${ }^{*}$ Number of parameters

${ }^{\S}$ AICc values for top model: Barn 1428.2; Cliff 664.1; Tree 2337.8.
For Cliff Swallows, our top four best-fit models $(\triangle \mathrm{AICc} \leq 2.0)$ for nestling mass included $\mathrm{IA}_{\mathrm{B} 1}$ (one model), $\mathrm{IA}_{\mathrm{MB}}$ (one model), or hatching date (two models; Table 5). Site and year were included in all four models, and brood size was included in one model. Model averaged parameter estimates showed that site and year were the most important predictors of nestling mass (Table 6) and nestling mass was higher at JO than WE (Table A1.1), and in 2015 compared to 2014. Model averaged confidence intervals for $\mathrm{IA}_{\mathrm{B} 1}$, $\mathrm{IA}_{\mathrm{MB}}$, hatching date, and brood size included zero, indicating little evidence that these variables affected nestling mass.

For Tree Swallows, our top two best-fit models $(\triangle \mathrm{AICc} \leq 2.0)$ for nestling mass included hatching date and the null model (Table 5). Again, model averaged confidence intervals for hatching date included zero, indicating little evidence that this variable affected nestling mass (Table 6).

\section{DISCUSSION}

The goal of our study was to examine the relationships between insect abundance and breeding success for three declining aerial insectivores. In doing so, we determined if low insect abundance (as a potential cause of population declines) was associated with lower reproductive success, and if all three species were similarly affected by low insect abundance suggesting a common driver of declines. At our sites, late breeding was associated with lower insect abundance during nestling rearing for Cliff and Tree Swallows. This suggested a potential cost for late-breeding birds, but low insect abundance was not related to decreased nestling survival and mass for the species studied. These results are consistent with Nooker et al. (2005), but differ from the results of several previous studies showing that periods of low insect abundance are associated with reduced nestling survival and body condition in Tree Swallows (Quinney et al. 1986, McCarty and Winkler 1999a, Winkler et al. 2013), and reduced postfledgling survival in Barn Swallows (Grüebler and Naef-Daenzer 2008). We suggest four possible explanations for our results.

First, it is possible that our samples did not reflect the food provided to nestlings (but see Quinney and Ankney 1985). 
Table 6. Averaged model coefficients with adjusted SE and confidence intervals (CI) from the best-fit models for Barn (Hirundo rustica), Cliff (Petrochelidon pyrrhonota), and Tree Swallow (Tachycineta bicolor) nestling mass.

\begin{tabular}{|c|c|c|c|c|c|c|}
\hline Species & Coefficients $^{\dagger}$ & Estimate & $\mathrm{SE}$ & Lower 95\% CI & Upper $95 \%$ CI & $\begin{array}{c}\text { Relative importance } \\
\left(\mathrm{S}^{*}\right)\end{array}$ \\
\hline \multirow[t]{3}{*}{ Barn } & intercept & 282.51 & 11.35 & 260.05 & 304.97 & - \\
\hline & $\mathrm{IA}_{\mathrm{B} 1}$ & 27.01 & 25.62 & -6.60 & 82.52 & $0.71(1)$ \\
\hline & $\mathrm{IA}_{\mathrm{MB}}^{\mathrm{B} 1}$ & 6.38 & 16.26 & -25.11 & 69.33 & 0.29 (1) \\
\hline \multirow[t]{7}{*}{ Cliff } & intercept & -5141.00 & 1569.00 & -8244.76 & -2036.75 & - \\
\hline & $\mathrm{IA}_{\mathrm{Bl}}$ & -0.16 & 0.44 & -2.11 & 0.66 & $0.21(1)$ \\
\hline & $\mathrm{IA}_{\mathrm{MB}}^{\mathrm{B} 1}$ & 0.00 & 0.31 & -1.63 & 1.57 & 0.14 (1) \\
\hline & HD & -0.75 & 0.83 & -2.69 & 0.34 & $0.64(2)$ \\
\hline & brood size & -0.23 & 0.46 & -1.81 & 0.39 & $0.33(1)$ \\
\hline & site WE & -2.35 & 0.76 & -3.85 & -0.85 & $1.00(4)$ \\
\hline & year 2015 & 2.56 & 0.78 & 1.02 & 4.10 & $1.00(4)$ \\
\hline \multirow[t]{2}{*}{ Tree } & intercept & 22.25 & 0.14 & 21.98 & 22.52 & - \\
\hline & HD & 0.17 & 0.26 & -0.14 & 0.93 & $0.42(1)$ \\
\hline
\end{tabular}

Abbreviations: $\mathrm{IA}_{\mathrm{M}}=$ mean insect abundance up to and including day 12 ; and $\mathrm{HD}=$ hatching date.

Number of averaged models.

However, our nets were placed in suitable foraging habitat for all three species (McCarty and Winkler 1999b, Ambrosini et al. 2002, Evans et al. 2007, Hussell 2012, Brown et al. 2017), and all three species were observed foraging near the nets (T. L. Imlay, personal observation). The placement (both distance from nesting sites and height) of our nets was also within the typical foraging range of breeding Barn and Tree Swallows (distance: up to 400 or $200 \mathrm{~m}$, respectively; height: < 10 or $12 \mathrm{~m}$, respectively; Brown and Bomberger Brown 1999b, McCarty and Winkler 1999b, Ambrosini et al. 2002). Less is known about the foraging ecology of Cliff Swallows, but this species forages within $1 \mathrm{~km}$ of its nesting site and from $0.5-30 \mathrm{~m}$ or higher above ground (Brown and Bomberger Brown 1996). Finally, our sampling was likely sufficient because the samples contained a large proportion of insects $(86.5 \%)$ that are common food items for all three species (summarized in Brown and Bomberger Brown 1999b, Winkler et al. 2011, Brown et al. 2017).

Second, other measures of insect abundance, like nutritional quality, may be more important than total abundance for nestling survival and mass (de Ayala et al. 2006, Twining et al. 2016). However, all three of our sites were located near wetlands and/or waterbodies that would presumably provide large numbers of high-quality insects for these species (Twining et al. 2016).

It is also possible that although we observed periods of low insect abundance these levels were not low enough to affect nestling survival or mass. Years with low nestling survival as a result of low insect abundance are infrequent for Tree Swallows at other sites (Winkler et al. 2013). In these cases, low nestling survival is the result of prolonged periods of cold temperatures (Winkler et al. 2013). Similarly, low food availability, partly as a result of lower temperatures, can also affect mass gain in Tree Swallow nestlings (Quinney et al. 1986, McCarty and Winkler 1999a, but see Nooker et al. 2005). Prolonged periods of cold temperatures were not observed during our study, and Barn and Tree Swallow nestling survival rates were $>90 \%$ in both years. Therefore it is possible that our study occurred during two years with plentiful food.

Finally, it is possible that periods of low insect abundance were offset by increased foraging effort by adult swallows, which would buffer nestlings from the effects of low insect abundance. Adults may buffer nestlings from periods of low insect abundance through (1) decreased foraging effort in poor conditions, but substantially increased foraging effort in good conditions resulting in large nestling fat stores (Schifferli et al. 2014), or (2) providing stable food provisioning rates across varying degrees of insect abundance through increased foraging effort (Hussell 1988, McCarty and Winkler 1999a, Bortolotti et al. 2011). Both strategies would reduce the potential effect of low insect abundance on nestling mortality and mass, but at a potential cost to adult survival (Saino et al. 1999, Ardia 2005). The role of the latter three possible explanations on Barn, Cliff, and Tree Swallows may differ between species, and they are not mutually exclusive.

Our results indicate that insect abundance (within the range of abundances we sampled) did not affect the nestling survival or mass of Barn, Cliff, and Tree Swallows at our sites. It is difficult to conclude based on the restricted geographic range of our study and the limited duration of the work that insect abundance does not affect breeding success. However, other research demonstrating relationships between insect abundance and breeding success was also carried out at sites with similarly restricted range (Quinney et al. 1986, McCarty and Winkler 1999a, Winkler et al. 2013) and during a similar time frame as our study, i.e., two years (Quinney et al. 1986).

Our results also indicate that while insect abundance was unrelated to breeding success for all three species, nestling survival for Cliff Swallows was lower $(65.5 \%$ surviving to day 12$)$ than Barn and Tree Swallows (> 90\%). Reduced nestling survival for Cliff Swallows may be explained by high levels of ectoparasitism (Brown and Bomberger Brown 1999a), or high nest temperatures as a result of nesting under metal roofs (D. Nickerson, T. L. Imlay, and A. G. Horn, unpublished data), both of which are correlated with hatching date and could have a greater effect on nestling survival and mass than insect abundance.

Insect availability has been suggested as a possible explanation for declines in aerial insectivores, including swallows, across North America (Nebel et al. 2010, Shutler et al. 2012). The 
concept of a common driver for aerial insectivore declines, in this case, insect abundance, is appealing for conservation efforts because, presumably, if the driver was addressed it would benefit multiple species. However, despite sampling in an area where population declines for all three species are particularly steep (Nebel et al. 2010, Shutler et al. 2012, Michel et al. 2016), insect abundance did not affect swallow breeding success. The effect of insect abundance on aerial insectivore breeding success may be constrained to areas experiencing land use changes, e.g., loss of livestock and agricultural intensification, which, in addition to weather conditions, may also reduce insect abundance (Møller 2001, Ambrosini et al. 2002, Ghilain and Bélisle 2008). Broadscale, multispecies research is needed to address the complex effects of potential drivers of population declines on aerial insectivores.

Responses to this article can be read online at: http://www.ace-eco.org/issues/responses.php/1092

\section{Acknowledgments:}

We thank the field assistants and volunteers involved in data collection and insect identification, and D. Hussell for advice on insect sampling. We also thank the private landowners, Acadia University, Ducks Unlimited Canada, Environment and Climate Change Canada, and Parks Canada for permitting access to their properties for field research. We gratefully acknowledge the support of P. Thomas and B. Whittam at Environment and Climate Change Canada, and helpful comments on the manuscript and data analysis from A. Horn, A. MacNeil, and three anonymous reviewers. This research was funded by (in alphabetical order) the Canadian Wildlife Federation, Environment and Climate Change Canada, the Natural Sciences and Engineering Research Council of Canada, New Brunswick Wildlife Trust Fund, Nova Scotia Habitat Conservation Fund, and Wildlife Preservation Canada. Swallow nest monitoring, capture, and handling of nestling swallows, and the collection of insect samples was approved by the Dalhousie University Animal Ethics Committee (protocol nos. 14-007, 14-025).

\section{LITERATURE CITED}

Ambrosini, R., A. M. Bolzern, L. Canova, S. Arieni, A. P. Møller, and N. Saino. 2002. The distribution and colony size of Barn Swallows in relation to agricultural land use. Journal of Applied Ecology 39:524-534. http://dx.doi.org/10.1046/j.1365-2664.2002.00721. $\mathrm{x}$

Ardia, D. R. 2005. Tree Swallows trade off immune function and reproductive effort differently across their range. Ecology 86:2040-2046. http://dx.doi.org/10.1890/04-1619

Barton, K. 2016. MuMIn: multi-model inference. $R$ package version 1.15.6. R Foundation for Statistical Computing, Vienna, Austria.

Bates, D., M. Mächler, B. Bolker, and S. Walker. 2015. Fitting linear mixed-effects models using lme4. Journal of Statistical Software 67:1-48. http://dx.doi.org/10.18637/jss.v067.i01
Bortolotti, L. E., V. B. Harriman, R. G. Clark, and R. D. Dawson. 2011. Can changes in provisioning by parent birds account for seasonally declining patterns of offspring recruitment? Canadian Journal of Zoology 89:921-928. http://dx.doi.org/10.1139/ z11-068

Both, C., S. Bouwhuis, C. M. Lessells, and M. E. Visser. 2006. Climate change and population declines in a long-distance migratory bird. Nature 441:81-83. http://dx.doi.org/10.1038/ nature 04539

Both, C., M. Van Asch, R. G. Bijlsma, A. B. Van Den Burg, and M. E. Visser. 2009. Climate change and unequal phenological changes across four trophic levels: constraints or adaptations? Journal of Animal Ecology 78:73-83. http://dx.doi.org/10.1111/ j.1365-2656.2008.01458.x

Boulton, R. L., Y. Richard, and D. P. Armstrong. 2008. Influence of food availability, predator density and forest fragmentation on nest survival of New Zealand robins. Biological Conservation 141:580-589. http://dx.doi.org/10.1016/j.biocon.2007.12.007

Brown, C. R., and M. Bomberger Brown. 1996. Coloniality in the Cliff Swallow: the effect of group size on social behavior. University of Chicago Press, Chicago, Illinois, USA.

Brown, C. R., and M. Bomberger Brown. 1999a. Fitness components associated with laying date in the Cliff Swallow. Condor 101:230-245. http://dx.doi.org/10.2307/1369986

Brown, C. R., and M. Bomberger Brown. 1999b. Barn Swallow (Hirundo rustica). In P. G. Rodewald, editor. The birds of North America. Cornell Lab of Ornithology, Ithaca, New York, USA. http://dx.doi.org/10.2173/bna.452

Brown, C. R., M. Bomberger Brown, P. Pyle, and M. A. Patten. 2017. Cliff Swallow (Petrochelidon pyrrhonata). In P. G. Rodewald, editor. The birds of North America. Cornell Lab of Ornithology, Ithaca, New York, USA. http://dx.doi.org/10.2173/ bna.cliswa.03

Brzęk, P., and M. Konarzewski. 2004. Effect of refeeding on growth, development, and behavior of undernourished Bank Swallow (Riparia riparia) nestlings. Auk 121:1187-1198. http://dx doi.org/10.1642/0004-8038(2004)121[1187:EOROGD]2.0.CO;2

Burger, C., E. Belskii, T. Eeva, T. Laaksonen, M. Mägi, R. Mänd, A. Qvarnström, T. Slagsvold, T. Veen, M. E. Visser, K. L. Wiebe, C. Wiley, J. Wright, and C. Both. 2012. Climate change, breeding date and nestling diet: how temperature differentially affects seasonal changes in Pied Flycatcher diet depending on habitat variation. Journal of Animal Ecology 81:926-936. http://dx.doi. org/10.1111/j.1365-2656.2012.01968.x

Burnham, K. P., and D. R. Anderson. 2002. Model selection and multimodel inference: a practical information-theoretical approach. Second edition. Springer-Verlag, New York, New York, USA. http://dx.doi.org/10.1007/b97636

Dawson, R. D. 2008. Timing of breeding and environmental factors as determinants of reproductive performance of Tree Swallows. Canadian Journal of Zoology 86:843-850. http://dx.doi. org/10.1139/Z08-065

de Ayala, R. M., R. Martinelli, and N. Saino. 2006. Vitamin E supplementation enhances growth and condition of nestling Barn 
Avian Conservation and Ecology 12(2): 19

Swallows (Hirundo rustica). Behavioral Ecology and Sociobiology 60:619-630. http://dx.doi.org/10.1007/s00265-006-0206-0

Dunn, P. O., D. W. Winkler, L. A. Whittingham, S. J. Hannon, and R. J. Robertson. 2011. A test of the mismatch hypothesis: how is timing of reproduction related to food abundance in an aerial insectivore? Ecology 92:450-461. http://dx.doi.

org/10.1890/10-0478.1

Evans, K. L., J. D. Wilson, and R. B. Bradbury. 2007. Effects of crop type and aerial invertebrate abundance on foraging Barn Swallows Hirundo rustica. Agriculture, Ecosystems \& Environment 122:267-273. http://dx.doi.org/10.1016/j.agee.2007.01.015

Ghilain, A., and M. Bélisle. 2008. Breeding success of Tree Swallows along a gradient of agricultural intensification. Ecological Applications 18:1140-1154. http://dx.doi.org/10.1890/07-1107.1

Grueber, C. E., S. Nakagawa, R. J. Laws, and I. G. Jamieson. 2011. Multimodel inference in ecology and evolution: challenges and solutions. Journal of Evolutionary Biology 24:699-711. http://dx. doi.org/10.1111/j.1420-9101.2010.02210.x

Grüebler, M. U., and B. Naef-Daenzer. 2008. Postfledging parental effort in Barn Swallows: evidence for a trade-off in the allocation of time between broods. Animal Behaviour 75:1877-1884. http://dx.doi.org/10.1016/j.anbehav.2007.12.002

Hovorka, M. D., and R. J. Robertson. 2000. Food stress, nestling growth, and fluctuating asymmetry. Canadian Journal of Zoology 78:28-35. http://dx.doi.org/10.1139/z99-183

Hussell, D. J. T. 1988. Supply and demand in Tree Swallow broods: a model of parent-offspring food-provisioning interactions in birds. American Naturalist 131:175-202. http://dx.doi.org/10.1086/284785

Hussell, D. J. T. 2012. The influence of food abundance on nestbox occupancy and territory size in the Tree Swallow, a species that does not defend a feeding territory. Condor 114:595-605. http://dx.doi.org/10.1525/cond.2012.100231

Hussell, D. J. T., and T. E. Quinney. 1987. Food abundance and clutch size of Tree Swallows Tachycineta bicolor. Ibis 129:243-258. http://dx.doi.org/10.1111/j.1474-919X.1987.tb03204.x

Law, A. A., M. E. Threlfall, B. A. Tijman, E. M. Anderson, S. McCann, G. Searing, and D. Bradbeer. 2017. Diet and prey selection of Barn Swallows (Hirundo rustica) at Vancouver International Airport. Canadian Field-Naturalist 131:26-31. http://dx.doi.org/10.22621/cfn.v131i1.1777

Lima, S. L. 2009. Predators and the breeding bird: behavioral and reproductive flexibility under the risk of predation. Biological Reviews 84:485-513. http://dx.doi.org/10.1111/j.1469-185X.2009.00085. $\mathrm{x}$

Martin, T. E. 1987. Food as a limit on breeding birds: a life-history perspective. Annual Review of Ecology and Systematics 18:453-487. http://dx.doi.org/10.1146/annurev.es.18.110187.002321

McCarty, J. P. 2001. Variation in growth of nestling Tree Swallows across multiple temporal and spatial scales. Auk 118:176-190. http://dx.doi.org/10.1642/0004-8038(2001)118[0176:VIGONT]2.0. $\mathrm{CO} ; 2$

McCarty, J. P., and D. W. Winkler. 1999a. Relative importance of environmental variables in determining the growth of nestling
Tree Swallows Tachycineta bicolor. Ibis 141:286-296. http://dx. doi.org/10.1111/j.1474-919X.1999.tb07551.x

McCarty, J. P., and D. W. Winkler. 1999b. Foraging ecology and diet selectivity of Tree Swallows feeding nestlings. Condor 101:246-254. http://dx.doi.org/10.2307/1369987

Michel, N. L., A. C. Smith, R. G. Clark, C. A. Morrissey, and K. A. Hobson. 2016. Differences in spatial synchrony and interspecific concordance inform guild-level population trends for aerial insectivorous birds. Ecography 39:774-786. http://dx. doi.org/10.1111/ecog.01798

Møller, A. P. 1994. Phenotype-dependent arrival time and its consequences in a migratory bird. Behavioral Ecology and Sociobiology 35:115-122. http://dx.doi.org/10.1007/BF00171501

Møller, A. P. 2001. The effect of dairy farming on Barn Swallow Hirundo rustica abundance, distribution and reproduction. Journal of Applied Ecology 38:378-389. http://dx.doi.org/10.1046/ j.1365-2664.2001.00593.x

Naef-Daenzer, B., and M. U. Grüebler. 2016. Post-fledging survival of altricial birds: ecological determinants and adaptation. Journal of Field Ornithology 87:227-250. http://dx. doi.org/10.1111/jofo.12157

Nakagawa, S., and R. P. Freckleton. 2011. Model averaging, missing data and multiple imputation: a case study for behavioural ecology. Behavioral Ecology and Sociobiology 65:103-116. http://dx.doi.org/10.1007/s00265-010-1044-7

Nebel, S., A. Mills, J. D. McCracken, and P. D. Taylor. 2010. Declines of aerial insectivores in North America follow a geographic gradient. Avian Conservation and Ecology 5(2):1. http://dx.doi.org/10.5751/ACE-00391-050201

Nooker, J. K., P. O. Dunn, and L. A. Whittingham. 2005. Effects of food abundance, weather, and female condition on reproduction in Tree Swallows (Tachycineta bicolor). Auk 122:1225-1238. http://dx.doi.org/10.1642/0004-8038(2005)122[1225: EOFAWA]2.0.CO;2

Owens, I. P. F., and P. M. Bennett. 1994. Mortality costs of parental care and sexual dimorphism in birds. Proceedings of the Royal Society B: Biological Sciences 257:1-8. http://dx.doi. org/10.1098/rspb.1994.0086

Quinney, T. E., and C. D. Ankney. 1985. Prey size selection by Tree Swallows. Auk 102:245-250. http://dx.doi.org/10.2307/4086766

Quinney, T. E., D. J. T. Hussell, and C. D. Ankney. 1986. Sources of variation in growth of Tree Swallows. Auk 103:389-400.

R Core Team. 2016. R: A language and environment for statistical computing. R Foundation for Statistical Computing, Vienna, Austria.

Raja-aho, S., T. Eeva, P. Suorsa, J. Valkama, and E. Lehikoinen. 2017. Juvenile Barn Swallows Hirundo rustica L. from late broods start autumn migration younger, fuel less effectively and show lower return rates than juveniles from early broods. Ibis 159:892-901. http://dx.doi.org/10.1111/ibi.12492

Rioux Paquette, S., D. Garant, F. Pelletier, and M. Bélisle. 2013. Seasonal patterns in Tree Swallow prey (Diptera) abundance are affected by agricultural intensification. Ecological Applications 23:122-133. http://dx.doi.org/10.1890/12-0068.1 
RStudio Team. 2015. RStudio: integrated development for $R$. RStudio Inc., Boston, Massachusetts, USA.

Saino, N., S. Calza, P. Ninni, and A. P. Møller. 1999. Barn Swallows trade survival against offspring condition and immunocompetence. Journal of Animal Ecology 68:999-1009. http://dx.doi.org/10.1046/j.1365-2656.1999.00350.x

Sauer, J. R., J. E. Hines, J. E. Fallon, K. L. Pardieck, J. D. J. Ziolkowski, and W. A. Link. 2014. The North American Breeding Bird Survey, results and analysis 1966-2013. Version 01.30.2015. U.S. Geological Survey Patuxent Wildlife Research Center, Laurel, Maryland, USA.

Schifferli, L., M. U. Grüebler, H. A. J. Meijer, G. H. Visser, and B. Naef-Daenzer. 2014. Barn Swallow Hirundo rustica parents work harder when foraging conditions are good. Ibis 156:777-787. http://dx.doi.org/10.1111/ibi.12186

Schwagmeyer, P. L., and D. W. Mock. 2008. Parental provisioning and offspring fitness: size matters. Animal Behaviour 75:291-298. http://dx.doi.org/10.1016/j.anbehav.2007.05.023

Shutler, D., D. J. T. Hussell, D. R. Norris, D. W. Winkler, R. J. Robertson, F. Bonier, W. B. Rendell, M. Bélisle, R. G. Clark, R. D. Dawson, N. T. Wheelwright, M. P. Lombardo, P. A. Thorpe, M. A. Truan, R. Walsh, M. L. Leonard, A. G. Horn, C. M. Vleck, D. Vleck, A. P. Rose, L. A. Whittingham, P. O. Dunn, K. A. Hobson, and M. T. Stanback. 2012. Spatiotemporal patterns in nest box occupancy by Tree Swallows across North America. Avian Conservation and Ecology 7(1):3. http://dx.doi.org/10.5751/ ACE-00517-070103

Smith, A. C., M.-A. R. Hudson, C. M. Downes, and C. M. Francis. 2015. Change points in the population trends of aerialinsectivorous birds in North America: synchronized in time across species and regions. PLOS ONE 10:e0130768. http://dx.doi. org/10.1371/journal.pone.0130768

Soler, J. J., A. P. Møller, and M. Soler. 1998. Nest building, sexual selection and parental investment. Evolutionary Ecology 12:427-441. http://dx.doi.org/10.1023/A:1006520821219

Stoner, D. 1935. Temperature and growth studies on the Barn Swallow. Auk 52:400-407. http://dx.doi.org/10.2307/4077512

Stoner, D. 1945. Temperature and growth studies of the northern Cliff Swallow. Auk 62:207-216. http://dx.doi.org/10.2307/4079698

Twining, C. W., J. T. Brenna, P. Lawrence, J. R. Shipley, T. N. Tollefson, and D. W. Winkler. 2016. Omega-3 long-chain polyunsaturated fatty acids support aerial insectivore performance more than food quantity. Proceedings of the National Academy of Sciences 113:10920-10925. http://dx.doi. org/10.1073/pnas.1603998113

Verhulst, S., and J.-Å. Nilsson. 2008. The timing of birds' breeding seasons: a review of experiments that manipulated timing of breeding. Philosophical Transactions of the Royal Society B: Biological Sciences 363:399-410. http://dx.doi.org/10.1098/ rstb.2007.2146

Visser, M. E., L. J. M. Holleman, and P. Gienapp. 2006. Shifts in caterpillar biomass phenology due to climate change and its impact on the breeding biology of an insectivorous bird Oecologia 147:164-172. http://dx.doi.org/10.1007/s00442-005-0299-6

Wardrop, S. L., and R. C. Ydenberg. 2003. Date and parental quality effects in the seasonal decline in reproductive performance of the Tree Swallow Tachycineta bicolor: interpreting results in light of potential experimental bias. Ibis 145:439-447. http://dx. doi.org/10.1046/j.1474-919X.2003.00184.x

Wickham, H. 2011. The split-apply-combine strategy for data analysis. Journal of Statistical Software 40:1-29. http://dx.doi. org/10.18637/jss.v040.i01

Winkler, D. W., K. K. Hallinger, D. R. Ardia, R. J. Robertson, B. J. Stutchbury, and R. R. Cohen. 2011. Tree Swallow (Tachycineta bicolor). In P. G. Rodewald, editor. The birds of North America. Cornell Lab of Ornithology, Ithaca, New York, USA. http://dx. doi.org/10.2173/bna.11

Winkler, D. W., M. K. Luo, and E. Rakhimberdiev. 2013. Temperature effects on food supply and chick mortality in Tree Swallows (Tachycineta bicolor). Oecologia 173:129-138. http://dx. doi.org/10.1007/s00442-013-2605-z
Editor-in-Chief: Keith A.Hobson Subject Editor: Jean-Pierre L.Savard
Sponsored by the Society of Canadian Ornithologists and Bird Studies Canada Parrainée par la Société des ornithologistes du Canada et Études d'oiseaux Canada 
Appendix 1. Supplemental information on sample sizes, variation in hatching dates, nestling survival, and mass for Barn Hirundo rustica, Cliff Petrochelidon pyrrhonota, and Tree Swallows Tachycineta bicolor, and variation in insect abundance (daily, IAM, IAB1, IAMB) during our study.

Table A1.1. Summary of the number of nests, mean \pm SE hatching dates, and nestling mass, and nestling survival for each species and the number of insect samples and mean \pm SE insect abundance by site.

\begin{tabular}{|c|c|c|c|c|c|}
\hline & variable $\dagger$ & BEFV & JO & WE & total \\
\hline \multirow[t]{4}{*}{ Barn } & $\mathrm{N}$ & 2 & 11 & 17 & 30 \\
\hline & $\begin{array}{l}\text { mean } \pm \text { SE HD } \\
\quad(\text { range })\end{array}$ & $\begin{array}{l}52.0 \pm 3.0 \\
(49-55)\end{array}$ & $\begin{array}{l}55.6 \pm 2.2 \\
(47-74)\end{array}$ & $\begin{array}{l}52.7 \pm 1.5 \\
(42-63)\end{array}$ & $\begin{array}{l}53.7 \pm 1.1 \\
(42-74)\end{array}$ \\
\hline & $\begin{array}{l}\text { surviving nestlings } \\
\quad(\%)\end{array}$ & $\begin{array}{l}10 / 10 \\
(100.0)\end{array}$ & $\begin{array}{l}39 / 39 \\
(100.0)\end{array}$ & $\begin{array}{l}71 / 75 \\
(94.7)\end{array}$ & $\begin{array}{l}120 / 124 \\
(96.8)\end{array}$ \\
\hline & $\begin{array}{c}\text { mean } \pm \text { SE nestling } \\
\text { mass (range) } \ddagger\end{array}$ & $\begin{array}{l}18.20 \pm 0.74 \\
(13.0-21.0)\end{array}$ & $\begin{array}{l}16.11 \pm 0.36 \\
(10.5-20.0)\end{array}$ & $\begin{array}{l}16.65 \pm 0.31 \\
(6.0-21.0)\end{array}$ & $\begin{array}{l}16.59 \pm 0.23 \\
(6.0-21.0)\end{array}$ \\
\hline \multirow[t]{4}{*}{ Cliff } & $\mathrm{N}$ & - & 25 & 26 & 51 \\
\hline & $\begin{array}{l}\text { mean } \pm \text { SE HD } \\
\quad(\text { range })\end{array}$ & - & $\begin{array}{l}51.5 \pm 0.8 \\
(42-58)\end{array}$ & $\begin{array}{l}55.3 \pm 1.1 \\
(41-63)\end{array}$ & $\begin{array}{l}53.4 \pm 0.7 \\
(41-63)\end{array}$ \\
\hline & $\begin{array}{l}\text { surviving nestlings } \\
\quad(\%)\end{array}$ & - & $\begin{array}{l}63 / 83 \\
(75.9)\end{array}$ & $\begin{array}{l}47 / 85 \\
(55.3)\end{array}$ & $\begin{array}{l}110 / 168 \\
(65.5)\end{array}$ \\
\hline & $\begin{array}{c}\text { mean } \pm \text { SE nestling } \\
\text { mass (range) } \$\end{array}$ & - & $\begin{array}{l}22.35 \pm 0.38 \\
(12.5-28.0)\end{array}$ & $\begin{array}{l}21.09 \pm 0.37 \\
(11.5-26)\end{array}$ & $\begin{array}{l}21.79 \pm 0.27 \\
(11.5-28)\end{array}$ \\
\hline \multirow[t]{4}{*}{ Tree } & $\mathrm{N}$ & 70 & 26 & 34 & 130 \\
\hline & $\begin{array}{l}\text { mean } \pm \text { SE HD } \\
\quad(\text { range })\end{array}$ & $\begin{array}{l}47.1 \pm 0.8 \\
(39-66)\end{array}$ & $\begin{array}{l}49.6 \pm 1.0 \\
(41-60)\end{array}$ & $\begin{array}{l}49.9 \pm 0.9 \\
(41-66)\end{array}$ & $\begin{array}{l}48.3 \pm 0.5 \\
(39-66)\end{array}$ \\
\hline & $\begin{array}{l}\text { surviving nestlings } \\
\text { (\%) }\end{array}$ & $\begin{array}{l}350 / 371 \\
(94.3)\end{array}$ & $\begin{array}{l}107 / 133 \\
(80.5)\end{array}$ & $\begin{array}{l}150 / 165 \\
(90.9)\end{array}$ & $\begin{array}{l}607 / 669 \\
(90.7)\end{array}$ \\
\hline & $\begin{array}{c}\text { mean } \pm \text { SE nestling } \\
\text { mass (range) } t\end{array}$ & $\begin{array}{l}22.42 \pm 0.10 \\
(15.5-27.5)\end{array}$ & $\begin{array}{l}22.35 \pm 0.22 \\
(15.0-27.0)\end{array}$ & $\begin{array}{l}21.89 \pm 0.16 \\
(16.0-26.0)\end{array}$ & $\begin{array}{l}22.28 \pm 0.08 \\
(15.0-27.5)\end{array}$ \\
\hline \multirow{5}{*}{$\begin{array}{l}\text { Insect } \\
\text { abundance }\end{array}$} & $\mathrm{N}$ & 64 & 65 & 68 & 197 \\
\hline & $\begin{array}{l}\text { mean } \pm \text { SE daily } \\
\quad \text { (range) }\end{array}$ & $\begin{array}{l}-0.55 \pm 0.06 \\
(-1.62-0.56)\end{array}$ & $\begin{array}{l}-0.70 \pm 0.08 \\
(-2.30-0.69)\end{array}$ & $\begin{array}{l}-0.78 \pm 0.07 \\
(-2.15-0.42)\end{array}$ & $\begin{array}{l}-0.68 \pm 0.04 \\
(-2.30-0.69)\end{array}$ \\
\hline & $\begin{array}{l}\text { mean } \pm \mathrm{SE} \mathrm{IA} \mathrm{I}_{\mathrm{M}} \\
\quad(\text { range })\end{array}$ & $\begin{array}{l}-0.33 \pm 0.02 \\
(-0.73--0.09)\end{array}$ & $\begin{array}{l}-0.42 \pm 0.02 \\
(-0.70--0.08)\end{array}$ & $\begin{array}{l}-0.46 \pm 0.01 \\
(-0.69--0.21)\end{array}$ & $\begin{array}{l}-0.41 \pm 0.01 \\
(-0.73--0.08)\end{array}$ \\
\hline & $\begin{array}{l}\text { mean } \pm \text { SE IA } \mathrm{B}_{\mathrm{B} 1} \\
\quad(\text { range })\end{array}$ & $\begin{array}{l}-0.33 \pm 0.02 \\
(-0.73--0.09)\end{array}$ & $\begin{array}{l}-0.42 \pm 0.02 \\
(-0.91--0.04)\end{array}$ & $\begin{array}{l}-0.45 \pm 0.01 \\
(-0.69--0.24)\end{array}$ & $\begin{array}{l}-0.40 \pm 0.01 \\
(-0.91--0.04)\end{array}$ \\
\hline & $\begin{array}{l}\text { mean } \pm \text { SE IA } \mathrm{IAB}_{\mathrm{MB}} \\
(\text { range })\end{array}$ & $\begin{array}{l}-0.47 \pm 0.04 \\
(-1.03-0.60)\end{array}$ & $\begin{array}{l}-0.64 \pm 0.05 \\
(-1.43-0.01)\end{array}$ & $\begin{array}{l}-0.60 \pm 0.05 \\
(-1.35-0.13)\end{array}$ & $\begin{array}{l}-0.57 \pm 0.03 \\
(-1.43-0.60)\end{array}$ \\
\hline
\end{tabular}

$\dagger$ Abbreviations: $\mathrm{N}=$ number of nests or daily samples, $\mathrm{HD}=$ hatching date, $\mathrm{IA}_{\mathrm{M}}=$ mean insect abundance up to and including day 12; and $\mathrm{IA}_{\mathrm{B} 1}=$ mean insect abundance on and one day prior to banding day; $\mathrm{IA}_{\mathrm{MB}}=$ mean insect abundance up to and including banding day.

+ Does not include nestling mass for nests where the mean nestling mass was than two standard deviations below the mean for all nests. 